\title{
Laporan Kasus: Feline Infectious Peritonitis Virus pada Kucing Lokal Jantan yang Mengalami Asites
}

\section{(CASE REPORT: FELINE INFECTIOUS PERITONITIS VIRUS IN MALE LOCAL CATS WITH ASCITES)}

\author{
Putu Devi Jayanti ${ }^{1 *}$, I Wayan Nico Fajar Gunawan ${ }^{1}$, Ni Luh Ayu Kartika Meidy \\ Pramudiasari Sulabda ${ }^{2}$ \\ ${ }^{1}$ Laboratorium Diagnosis Klinik, Patologi Klinik dan Radiologi, Fakultas Kedokteran Hewan \\ Universitas Udayana, Jl. PB. Sudirman, Denpasar, Bali; \\ ${ }^{2}$ Rumah Sakit Hewan Pendidikan Universitas Udayana, Jl. Raya Sesetan, Gg. Markisa No. 6 \\ Denpasar Selatan, Denpasar Bali. *Email: putudevijayanti@unud.ac.id
}

\begin{abstract}
Abstrak
Feline infectious peritonitis merupakan infeksi virus pada kucing dengan tanda klinis terjadi asites pada bentuk efusif. Asites merupakan bentuk umum keadaan sistemik yang ditandai dengan adanya distensi abdomen yang disebabkan karena adanya akumulasi cairan. Seekor kucing lokal berumur 1 (satu) tahun dengan bobot badan $4 \mathrm{~kg}$ bernama Minmin datang ke Rumah Sakit Hewan Pendidikan Universitas Udayana dengan keluhan terjadi penurunan nafsu makan, lemas, susah defekasi dan rongga abdomen membesar. Pada pemeriksaan fisik diketahui adanya distensi abdomen. Untuk peneguhan diagnosis dilakukan pemeriksaan ultrasonografi, rontgen, dan abdominocentesis dan diperoleh hasil bahwa terjadi akumulasi cairan pada rongga abdomen, hepatomegali, dan nefritis. Dilakukan pemeriksaan hematologi rutin dan biokimia darah yang menunjukkan adanya peradangan kronis dan abnormalitas fungsi ginjal. Hasil uji rivalta menunjukkan hasil positif akumulasi eksudat yang ditandai dengan bentukan jellyfish like. Terapi yang diberikan berupa pemberian diuretik furosemide $10 \mathrm{mg} / \mathrm{ml}$ injeksi intravena dengan jumlah pemberian $0,45 \mathrm{ml}(2 \mathrm{x}$ sehari), hepatoprotektor ornipural injeksi subkutan dengan jumlah pemberian $2 \mathrm{ml}$ (setiap 2 hari sekali), nefroprotektor ketosteril per oral dengan jumlah pemberian $1 / 2$ tablet (setiap 2 hari sekali), antibiotik cefotaxim sodium $1 \mathrm{~g} / \mathrm{ml}$ injeksi intravena dengan jumlah pemberian $1,3 \mathrm{ml}(2 \mathrm{x}$ sehari), antiradang dexamethasone $5 \mathrm{mg} / \mathrm{ml}$ injeksi subkutan dengan jumlah $0,4 \mathrm{ml}(2 \times$ sehari), dan transfer factor $1 \times 1$ tablet selama 7 hari. Pengobatan yang diberikan memberikan hasil yang baik terhadap penurunan derajat distensi abdomen.

Kata kunci: asites; suspect feline infectious peritonitis; kucing; tes rivalta
\end{abstract}

\section{Abstract}

Feline infectious peritonitis is a viral infection in cats with clinical signs of ascites occurring in the effusion form. Ascites are a common form of systemic state characterized by abdominal distention caused by fluid accumulation. A local cat aged 1year with a weight of $4 \mathrm{~kg}$ named Minmin came to Udayana University Animal Education Hospital with complaints of decreased appetite, weakness, difficulty defecation and abdominal cavity enlargement. On physical examination is known the presence of abdominal distension. For the edification of the diagnosis is carried out ultrasound examination, X-ray, and abdominocentesis. There is an accumulation of fluid in the abdominal cavity, hepatomegaly, and nephritis. Routine hematology and blood biochemical examinations are performed that indicate chronic inflammation and abnormalities in kidney function. Rivalta test results showed positive results of accumulated exudate characterized by jellyfish like formation. Therapy given in the form of diuretic administration furosemide $10 \mathrm{mg} / \mathrm{ml}$ intravenous injection with the amount of administration $0.45 \mathrm{ml}$ ( $2 \mathrm{x}$ daily), ornipural hepatoprotector subcutaneous injection with the amount of administration $2 \mathrm{ml}$ (every 2 days), nephroprotektor ketosteril per oral with a total administration of 1/2 tablet (every 2 days), antibiotic cefotaxim sodium $1 \mathrm{~g} / \mathrm{ml}$ intravenous injection with a total administration of $1.3 \mathrm{ml}(2 \mathrm{x}$ daily), anti-inflammatory dexamethasone $5 \mathrm{mg} / \mathrm{ml}$ subcutaneous injection with an amount of $0.4 \mathrm{ml}(2 \mathrm{x}$ daily), and transfer factor $1 \times 1$ tablet for 7 days. The treatment provided gives good results against a decrease in the degree of abdominal distention.

Key words: ascites; suspect feline infectious peritonitis; cat; rivalta test 


\section{PENDAHULUAN}

Kucing merupakan salah satu hewan peliharaan yang banyak dipilih untuk dipelihara oleh masyarakat. Hal tersebut menjadikan kucing merupakan salah satu hewan peliharaan yang sangat dekat dengan manusia. Manfaat pemeliharaan kucing dinyatakan dapat meningkatkan motivasi pemiliknya dalam berolahraga dan dapat menurunkan tingkat stress (Keat et al., 2016). Akan tetapi kurangnya pengetahuan terkait kesehatan hewan menyebabkan masih banyaknya diamati gangguan kesehatan pada kucing baik yang disebabkan oleh faktor infeksius maupun non infeksius. Salah satu gangguan kesehatan yang dapat menginfeksi kucing adalah feline infectious peritonitis.

Feline infectious peritonitis (FIP) merupakan salah satu infeksi virus dengan angka morbiditas dan mortalitas yang tinggi pada kucing. Infeksi bisa bersifat fatal pada kucing yang terinfeksi dengan ataupun tanda gejala klinis tertentu (Sharif et al., 2010). Virus dapat menyerang kucing liar maupun kucing domestik. Kasus lebih banyak dilaporkan terjadi pada kucing jantan dan kucing muda yang berumur dibawah 3 (tiga) tahun (Felten dan Hartmann, 2019). Penyakit ini disebabkan oleh bentuk mutasi dari agen infeksi feline coronavirus (FCoV) (Horhogea et al., 2011) yang diklasifikasikan pada genus Alphacoronavirus (Sifa-Shaida et al., 2020). Infeksi ini terdapat dalam 2 (dua) bentuk utama yaitu bentuk efusif dan nonefusif. Asites merupakan tanda klinis umum yang teramati pada bentuk efusif (Addie et al., 2009).

Asites merupakan bentuk umum keadaan sistemik yang dapat teramati dalam berbagai penyakit pada hewan. Kondisi ini merupakan salah satu tanda klinis dari satu atau beberapa penyakit yang terjadi (Neelam et al., 2019). Umumnya asites ditandai dengan adanya distensi abdomen yang disebabkan karena adanya akumulasi cairan. Tanda klinis ini dilaporkan berkaitan dengan penyakit hati kronis, gagal jantung kongestif, sindrom nefritik, malnutrisi, ancilostomiasis, dan rendahnya kadar protein darah khususnya albumin (Regmi dan Shah, 2017), berbagai tipe dari neoplasma (Dabas et al., 2011; Srinivas et al., 2020) serta peningkatan retensi ion natrium-sodium ginjal (Saravanan et al., 2014). Singh et al. (2019) menyatakan bahwa asites dapat terjadi pada hipertensi portal, hipoalbuminemia, dan retensi ginjal terhadap natrium dan air.

Terdapat beberapa metode diagnosis pada kasus asites diantaranya dengan pemeriksaan fisik, pemeriksaan hematologi, pencitraan radiologi, abdominocentesis, analisis biokimia darah, analisis sitologi cairan, biopsi dan tes fungsi organ (Regmi dan Shah, 2017). Selain itu juga diperlukan dilakukan pemeriksaan ultrasonografi (USG) (Kumar dan Srilaka, 2014) dan tes rivalta.

Perkembangan asites dikaitkan dengan prognosis yang buruk (Lenz et al., 2015). Seiring dengan bervariasinya gejala klinis pada kucing yang terinfeksi feline infectious peritonitis, metode diagnosis lebih lanjut menjadi tantangan di lapangan karena kompleksitas penyakit yang seringkali membutuhkan banyak pengujian laboratoris untuk mengkonfirmasi penyakit. Tujuan dari pengamatan ini adalah untuk mengetahui metode diagnosis sederhana pada kucing yang terinfeksi feline infectious peritonitis yang mengalami asites.

\section{METODE PENELITIAN}

\section{Rekam Medik \\ Sinyalemen dan Anamnesis}

Pengamatan ini dilakukan pada kucing lokal bernama Minmin dengan jenis kelamin jantan dan berumur 1 (satu) tahun. Kucing kasus memiliki bobot badan $4 \mathrm{~kg}$ dengan warna rambut kuning kecoklatan. Pemilik kucing bernama Gede Juli Parwata. Kucing kasus datang untuk melakukan pemeriksaan ke Rumah Sakit Hewan Pendidikan Fakultas Kedokteran Hewan Universitas Udayana (RSHP 
Unud) dengan keluhan terjadi penurunan nafsu makan, lemas, sudah defekasi dan rongga abdomen membesar. Hal tersebut telah diamati oleh pemilik selama 7 hari. Sebelum datang ke RSHP Unud, kucing kasus telah mendapatkan penanganan oleh dokter hewan namun belum menunjukkan perubahan yang signifikan.

Kucing kasus dipelihara dengan cara dilepas di dalam lingkungan rumah dengan satu (1) ekor kucing lainnya. Vaksinasi dan pemberian obat cacing sudah pernah dilakukan selama pemeliharaan. Kucing kasus biasanya diberikan pakan berupa dryfood dengan minum ad libitum.

\section{HASIL DAN PEMBAHASAN}

Hasil

Pemeriksaan Fisik

\section{Pemeriksaan Tanda Vital}

Pemeriksaan tanda vital dilakukan untuk mengetahui abnormalitas yang terjadi pada kucing kasus. Hasil pemeriksaan tanda vital kucing kasus disajikan pada Tabel 1 .

Tabel 1. Hasil pemeriksaan tanda vital kucing Minmin

\begin{tabular}{|c|c|c|c|}
\hline Parameter & Nilai & Referensi & Keterangan \\
\hline Suhu & $39,8^{0} \mathrm{C}$ & $37,8-39,5^{0} \mathrm{C}$ & $\mathrm{H}$ \\
\hline Frekuensi Nafas & $60 \mathrm{kali} / \mathrm{menit}$ & $20-30 \mathrm{kali} / \mathrm{menit}$ & $\mathrm{H}$ \\
\hline Ritme Nafas & Irregular & & \\
\hline Frekuensi Degup Jantung & $136 \mathrm{kali} / \mathrm{menit}$ & $130-140 \mathrm{kali} / \mathrm{menit}$ & $\mathrm{N}$ \\
\hline Ritme Degup Jantung & Irregular & & \\
\hline Frekuensi Pulsus & $140 \mathrm{kali} / \mathrm{menit}$ & $130-140 \mathrm{kali} / \mathrm{menit}$ & $\mathrm{N}$ \\
\hline Capillary refill time (CRT) & $\leq 2$ detik & & $\mathrm{N}$ \\
\hline Turgor Kulit & $\geq 2$ detik, lambat & & $\mathrm{H}$ \\
\hline
\end{tabular}

Keterangan: $\mathrm{H}=$ high (meningkat); $\mathrm{N}=$ normal (Plumb, 2008)

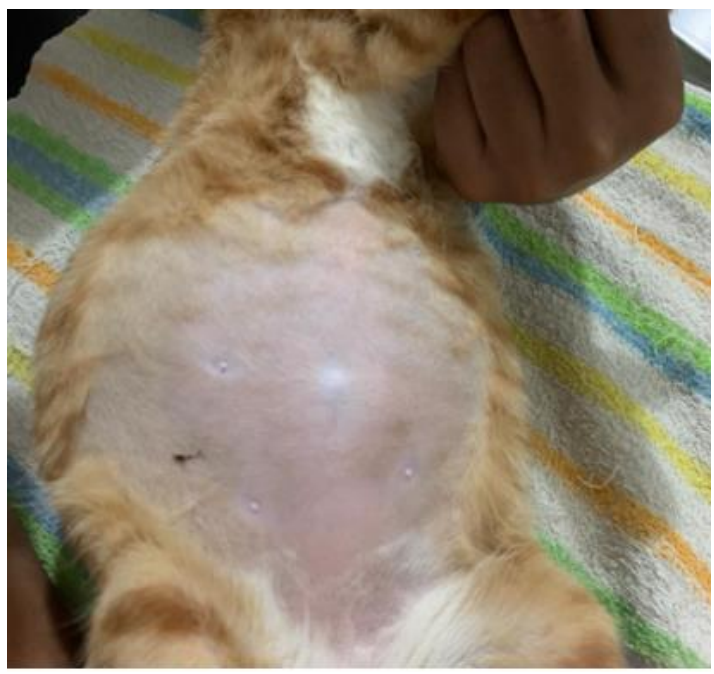

Gambar 1. Distensi Abdominal pada Kucing Minmin

\section{Pemeriksaan Sistem Organ}

Pada pemeriksaan fisik organ dengan cara inspeksi dan palpasi diperoleh hasil bahwa terjadi distensi abdominal. Pembesaran di daerah abdomen tersebut terlihat simetris, seperti membentuk buah pir (Gambar 1). Saat dilakukan palpasi berulang teramati adanya getaran cairan bergelombang pada daerah abdominal. Pemeriksaan muskoloskeletal tampak kelemahan pada otot sehingga kucing enggan untuk berdiri secara sempurna. Pemeriksaan pernafasan diperoleh hasil terjadinya takipneu dengan tipe pernafasan thorakalis. Pada pemeriksaan kulit, mata, telinga, dan pencernaan diperoleh hasil normal.

\section{Pemeriksaan Penunjang}

Untuk menunjang diagnosis dilakukan pemeriksaan roengent, ultrasonografi, hematologi, biokimia darah, abdominocentesis, dan tes Rivalta.

\section{Pemeriksaan Rontgen}

Pemeriksaan rontgen bertujuan untuk mengetahui adanya abnormalitas ukuran maupun bentuk dari organ yang diperiksa (Singh et al., 2019). Pemeriksaan rontgen pada kucing kasus dilakukan pada posisi lateral dan ventrodorsal pada regio abdomen. Hasil pemeriksaan 
menunjukkan adanya radioopasitas pada abdomen yang menggambarkan terjadi akumulasi cairan pada rongga abdomen. Berdasarkan hasil tersebut pada pencitraan lateral dan ventrodorsal terlihat kepadatan rongga abdomen meningkat secara difus (Gambar 2).

\section{Pemeriksaan Hematologi}

Pemeriksaan hematologi bertujuan untuk mengevaluasi abnormalitas kondisi yang terjadi pada kucing kasus melalui pemeriksaan darah. Hasil pemeriksaan hematologi pada kucing kasus menunjukkan bahwa terjadi leukositosis, granulositosis, limfositopenia (Tabel 2).
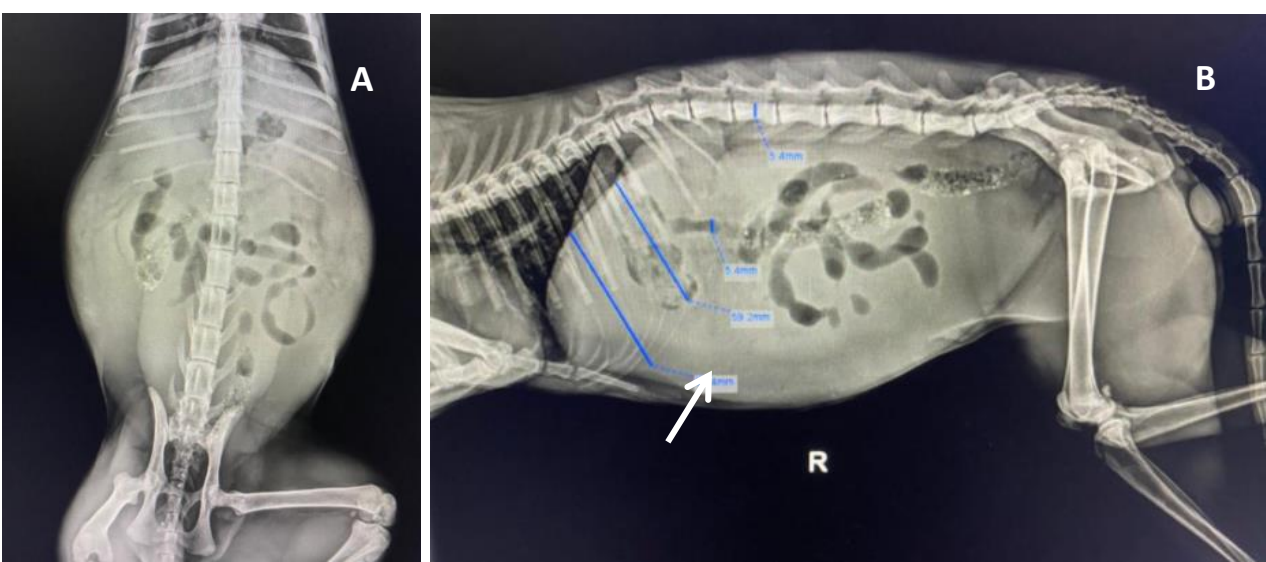

Gambar 2. Hasil Pemeriksaan roengent pada Regio Abdomen Kucing Minmin. Radioopasitas pada abdomen yang menunjukkan bahwa adanya akumulasi cairan pada pencitraan posisi ventrodorsal (A) dan lateral (B)

Tabel 2. Hasil pemeriksaan hematologi kucing Minmin

\begin{tabular}{lccc}
\hline \multicolumn{1}{c}{ Parameter } & Hasil & Parameter & Keterangan \\
\hline WBC $\left(10^{3} / \mu \mathrm{L}\right)$ & 38,1 & $5,5-19,5$ & H \\
Limfosit $\left(10^{3} / \mu \mathrm{L}\right)$ & 2,0 & $0,8-7$ & $\mathrm{~N}$ \\
Monosit $\left(10^{3} / \mu \mathrm{L}\right)$ & 1,3 & $0-1,9$ & $\mathrm{~N}$ \\
Granulosit $\left(10^{3} / \mu \mathrm{L}\right)$ & 34,8 & $2,1-15$ & $\mathbf{H}$ \\
Limfosit $(\%)$ & 5,3 & $12-45$ & $\mathbf{L}$ \\
Monosit $(\%)$ & 3,3 & $2-9$ & $\mathrm{~N}$ \\
Granulosit $(\%)$ & 91,4 & $35-85$ & $\mathbf{H}$ \\
Eritrosit $\left(10^{6} / \mu \mathrm{L}\right)$ & 6,93 & $6-10$ & $\mathrm{~N}$ \\
Hemoglobin $(\mathrm{g} / \mathrm{dL})$ & 11,3 & $9,5-15,3$ & $\mathrm{~N}$ \\
MCHC $(\mathrm{g} / \mathrm{dL})$ & 35,5 & $30-36$ & $\mathrm{~N}$ \\
MCH $(\mathrm{g} / \mathrm{dL})$ & 16,3 & $13-21$ & $\mathrm{~N}$ \\
MCV $(\mathrm{g} / \mathrm{dL})$ & 46,0 & $39-55$ & $\mathrm{~N}$ \\
RDW $(\%)$ & 17,3 & $13-17$ & $\mathbf{H}$ \\
HCT $(\%)$ & 31,8 & $29-45$ & $\mathrm{~N}$ \\
Platelet $\left(10^{9} / \mu \mathrm{L}\right)$ & 306 & $150-600$ & $\mathrm{~N}$ \\
MPV $(\mathrm{fL})$ & 11,1 & $5-11,8$ & $\mathrm{~N}$ \\
PDW $(\mathrm{fL})$ & 15,1 & $10-18$ & $\mathrm{~N}$ \\
PCT $(\%)$ & 0,339 & $0,1-0,5$ & $\mathrm{~N}$ \\
\hline
\end{tabular}

Keterangan: $\mathrm{H}=$ high (meningkat); $\mathrm{N}=$ normal; $\mathrm{L}=$ low (menurun) Sumber: Plumb (2008)

\section{Pemeriksaan Kimia Darah}

Pemeriksaan kimia darah bertujuan untuk mengukur dan mengevaluasi kadar dari beberapa zat kimia dalam darah. Pemeriksaan ini juga membantu mengetahui adanya abnormalitas kondisi 
yang terjadi pada kucing kasus melalui pemeriksaan darah. Hasil pemeriksaan kimia darah pada kucing kasus menunjukkan bahwa terjadi penurunan kadar glukosa, alkaline phosphatase, persentase albumin: globulin, serta terjadi peningkatan pada kadar blood urea nitrogen (BUN) (Tabel 3).

\section{Pemeriksaan Ultrasonografi}

Pemeriksaan

ultrasonografi merupakan prosedur pemindaian dengan menggunakan teknologi gelombang suara berfrekuensi tinggi. Tujuan dari pemeriksaan ini adalah untuk mengetahui gambaran organ tubuh bagian dalam sehingga dapat dievaluasi jika terjadinya abnormalitas (Gambar 3).

Tabel 3. Hasil Pemeriksaan kimia darah kucing Minmin

\begin{tabular}{lccc}
\hline \multicolumn{1}{c}{ Parameter } & Hasil & Parameter & Keterangan \\
\hline Glukosa (mg/dL) & 27 & $50-170$ & L \\
Kreatinin (mg/dL) & 1,2 & $0,6-2,4$ & $\mathrm{~N}$ \\
BUN (mg/dL) & 47 & $14-36$ & $\mathbf{H}$ \\
BUN/Kreatinin (mg/dL) & 40 & $4-33$ & $\mathbf{H}$ \\
Total Protein ( g/dL ) & 7,6 & $5,2-8,8$ & $\mathrm{~N}$ \\
Albumin ( g/dL ) & 2,5 & $2,6-3,9$ & $\mathbf{L}$ \\
Globulin ( g/dL ) & 5,1 & $2,3-5,3$ & $\mathrm{~N}$ \\
Albumin/Globulin & 0,5 & $0,8-2,0$ & $\mathbf{L}$ \\
ALT ( U/ L ) & 55 & $10-100$ & $\mathrm{~N}$ \\
ALP ( U/ L ) & $<10$ & $10-50$ & L \\
\hline
\end{tabular}

Keterangan: $\mathrm{H}=$ high (meningkat); $\mathrm{N}=$ normal; $\mathrm{L}=$ low (menurun)

Sumber: Klaassen (1999)
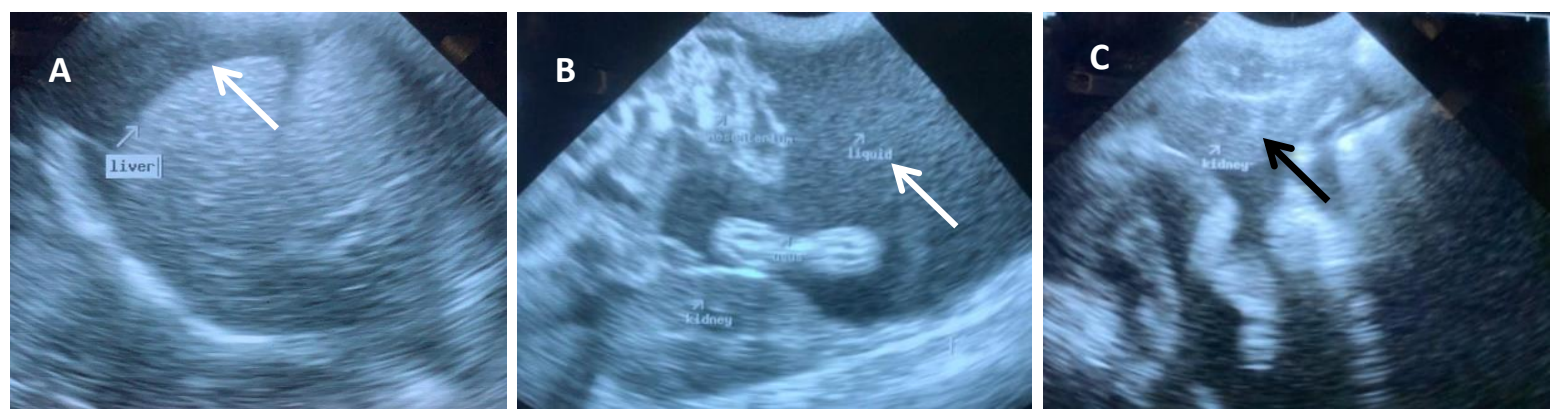

Gambar 3. Hasil pemeriksaan ultrasonografi menunjukkan terjadi penumpulan pada ujung hati (tanda panah putih) (A), adanya akumulasi cairan (citra anechoic) pada rongga abdomen (tanpa panah putih) (B), dan terjadi penebalan pada korteks renalis ditandai dengan perubahan echotexture menjadi lebih echogenic (tanda panah hitam) (C) (dok. Pribadi, 2021).
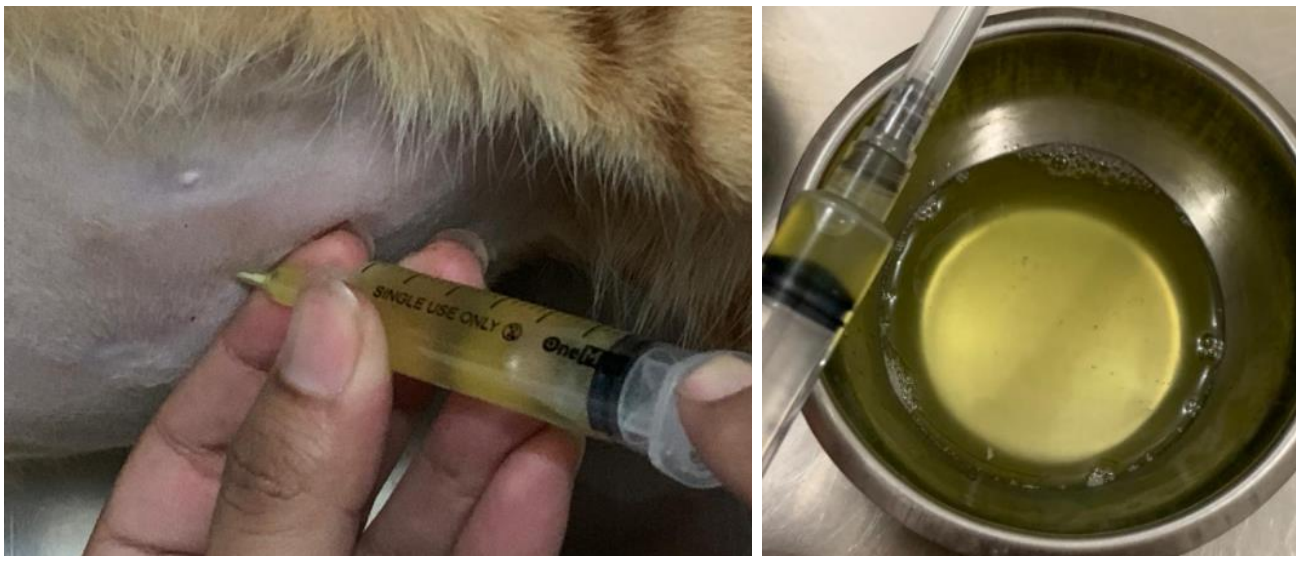
Gambar 4. Teknik Abdominocetesis dengan Cara Melakukan Aspirasi Cairan pada Rongga Abdomen (A). Terlihat adanya cairan kuning pucat dengan konsistensi cair mengental (B)

Hasil pemeriksaan ultrasonografi pada kucing kasus menunjukkan terjadinya hepatomegali dimana hal tersebut ditandai dengan adanya abnormalitas bentuk hati, adanya akumulasi cairan pada rongga abdomen, dan terjadinya peradangan pada ginjal (Gambar 3).

\section{Abdominocentesis}

Abdominocentesis merupakan teknik pengambillan cairan dari rongga abdomen. Pengambilan cairan ini dapat dilakukan dengan posisi berdiri ataupun lateral recumbency (Kusumawardhani et al., 2019). Koleksi akumulasi abdominal bertujuan untuk menganalisis keberadaan bakteri, adanya kandungan protein, dan perdarahan (Regmi dan Shah, 2017). Sebelum dilakukan koleksi, daerah abdomen dicukur dan disterilisasi terlebih dahulu. Koleksi cairan abdominal dilakukan dengan menggunakan IV kateter 24G dan syringe $5 \mathrm{ml}$ steril yang diinjeksikan pada rongga peritoneum dan diaspirasi secara berlahan. Hasil aspirasi cairan abdomen ditampung pada wadah steril. Hasil koleksi cairan abdomen berwarna kuning pucat dengan konsitensi cair mengental (Gambar 4).

\section{Tes Rivalta}

Tes rivalta merupakan sebuah uji sederhana yang bertujuan untuk membedakan cairan protein penyebab asites (Sharif et al., 2010). Reaksi positif pada tes ini mengkonfirmasi adanya kandungan protein tinggi (eksudat), kadar fibrinogen yang tinggi, dan adanya mediator inflamasi pada suatu efusi. Tes rivalta memiliki sensitivitas sebesar $91 \%$ dan spesifisitas sebesar $66 \%$, dengan nilai prediksi positif sebesar $58 \%$ dan negatif sebesar 93\% (Fischer et al., 2012). Hasil positif ditandai dengan tetesan hasil tetes cairan efusi yang secara perlahan melayang turun ke dasar tabung seperti ubur-ubur (jellyfish like) (Kusumawardhani et al., 2019). Tes rivalta yang diujikan pada kasus ini menunjukkan hasil positif yang menyatakan bahwa cairan hasil aspirasi abdomen yang diujikan merupakan eksudat (Gambar 5).

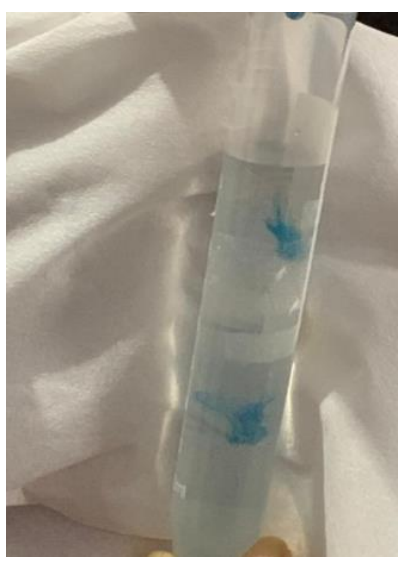

Gambar 5. Hasil Tes Rivalta yang Menunjukkan Hasil Positif, Ditunjukkan dengan Adanya Bentukan Jellyfish like pada Tetes Cairan Abdomen

\section{Diagnosis}

Berdasarkan anamnesis, pemeriksaan fisik dan pemeriksaan penunjang, disimpulkan bahwa kucing Minmin terinfeksi Feline Infectious Peritonitis bentuk efusif. Adapun diagnoasa banding untuk kasus kucing ini antara lain toxoplasmosis, infeksi mikobakteri, lymphocytic cholangitis, right heart failure, dan gagal ginjal kronis.

\section{Prognosis}

Prognosis hewan kasus adalah dubius - infausta.

\section{Terapi}

Kucing Minmin diterapi dengan pemberian diuretik furosemide $10 \mathrm{mg} / \mathrm{ml}$ injeksi intravena dengan jumlah pemberian $0,45 \mathrm{ml} \quad(2 \mathrm{x}$ sehari), hepatoprotektor ornipural injeksi subkutan dengan jumlah pemberian $2 \mathrm{ml}$ (setiap 2 hari sekali), nefroprotektor ketosteril per oral dengan jumlah pemberian $1 / 2$ tablet (setiap 2 hari sekali), anibiotik cefotaxim sodium $1 \mathrm{~g} / \mathrm{ml}$ injeksi intravena dengan jumlah pemberian 1,3 
$\mathrm{ml}$ ( $2 \mathrm{x}$ sehari), antiradang dexamethasone $5 \mathrm{mg} / \mathrm{ml}$ injeksi subkutan $0,4 \mathrm{ml}(2 \mathrm{x}$ sehari), dan transfer factor 1 x 1 tab selama 7 hari.

\section{Pembahasan}

Feline infectious peritonitis adalah infeksi virus yang menyerang kucing berbagai umur dan jenis. Infeksi ini disebabkan oleh mutasi dari agen Feline Coronavirus yang termasuk dalam famili Coronaviridae dan genus Alphacoronavirus (Sifa-Shaida et al., 2020). Penyakit ini dibedakan menjadi 2 (dua) bentuk yaitu bentuk non-efusi yang ditandai dengan adanya lesi pyogranulomatous pada organ serta bentuk efusi yang ditandai dengan terjadinya polyserositis (efusi abdomen atau thoraks) dan vaskulitis. Gejala klinis dari infeksi ini sangat bervariasi tergantung distribusi vaskulitis dan lesi pyogranulomatous (Addie et al., 2009). Asites merupakan tanda klinis yang umum teramati pada kucing dengan feline infectious peritonitis bentuk efusif (Pedersen, 2009).

Asites merupakan tanda klinis yang menunjukkan kondisi mendasar dari satu atau beberapa komplikasi penyakit serius. Kondisi ini memerlukan perawatan segera dan rasional sehingga penerapan dari beberapa metode diagnosa penting dilakukan untuk mendapatkan diagnosis yang tepat (Dabas et al., 2011; Kumar and Srilaka, 2014). Adapun metode diagnosa yang dilakukan pada kucing kasus antara lain pemeriksaan fisik berupa pemeriksaan tanda vital dan pemeriksaan sistem organ. Selain itu dilakukan juga pemeriksaan penunjang antara lain pemeriksaan radiologi, ultrasonografi, hematologi, biokimia darah, abdominocentesis, dan tes rivalta.

Status present menyatakan terjadinya peningkatan suhu pada kucing kasus yaitu $39,8^{0} \mathrm{C}$. Harkin (2017) menyatakan bahwa infeksi virus seperti feline infectious peritonitis dapat menyebabkan demam pireksia transien maupun persisten. Kisaran suhu normal pada kucing adalah $38,1^{\circ} \mathrm{C}$ hingga $39,2^{\circ} \mathrm{C}$. Pireksia pada kucing diklasifikasikan sebagai peningkatan suhu diatas $39,7^{0} \mathrm{C}$.

Pada pemeriksaan fisik diperoleh hasil bahwa terjadi distensi abdominal yang simetris. Saat diinspeksi terlihat bagian abdomen membesar seperti buah pir. Hal tersebut dikonfirmasi juga oleh Srinivas et al. (2020) yang menyatakan bahwa akumulasi cairan akan membentuk abdomen terlihat seperti buah pir. Saat dilakukan palpasi berulang teramati adanya getaran cairan yang bergelombang pada daerah abdominal. Kumar et al. (2016) menyebutkan bahwa palpasi bagian abdomen pada hewan asites akan menghasilkan pantulan getaran cairan bergelombang pada rongga abdominal.

Kucing kasus teramati mengalami kelemahan saat berdiri diduga karena adanya distensi abdomen yang kemudian menggangu kerja muskoloskeletal terutama pada organ ekstremitas caudal. Pada pemeriksaan pernafasan diamati adanya peningkatan frekuensi nafas dengan tipe pernafasan thorakalis. Hal tersebut disebabkan karena ada akumulasi cairan yang kemudian menekan rongga diafragma sehingga proses pengambilan nafas akan meningkat. Andrew (2020) menyebutkan bahwa tanda klinis awal dari infeksi Feline Coronavirus (FCoV) umumnya berupa gangguan pada saluran pernafasan atas dan gangguan pencernaan. Tanda klinis diikuti dengan timbulnya asites yang menyebabkan terjadinya distensi abdomen akibat akumulasi cairan (Hartmann, 2005). Selain itu terjadi efusi thorakalis dan peritoneum yang menyebabkan dispnea dan takipnea (Pedersen, 2014).

Hasil pemeriksaan rontgen menunjukkan perubahan radioopasitas pada abdomen karena adanya akumulasi cairan pada organ tersebut. Berdasarkan hasil tersebut pada pencitraan lateral dan ventrodorsal terlihat kepadatan rongga abomen yang meningkat secara difus. Sharif et al. (2010) menyatakan bahwa pada pemeriksaan radiografi kucing 
dengan feline infectious peritonitis menunjukkan adanya efusi peritoneal.

Pemeriksaan ultrasonografi penting dilakukan untuk mengkonfirmasi penyebab distensi abdomen (Pedersen, 2014). Sharif et al. (2010) menyatakan bahwa ultrasonografi digunakan untuk mengkonfirmasi adanya cairan pada abdomen dan untuk mengevaluasi organ pankreas, hati, limfonodus, dan ginjal. Hasil pemeriksaan ultrasonografi menunjukkan terjadinya hepatomegali dimana hal tersebut ditandai dengan adanya abnormalitas bentuk hati, adanya akumulasi cairan pada rongga abdomen, dan terjadinya peradangan pada ginjal, dimana terjadi perubahan echotexture pada korteks renalis yang seharusnya hypoechoic menjadi lebih echogenic dibandingkan gambaran normal ginjalnya. Hasil pencitraan lobus hati harus memiliki tepi yang halus meruncing sehingga apabila terjadi pembulatan pada tepi hati mengindikasikan terjadinya pembesaran organ (Griffin, 2019). Peningkatan ekogenesitas dari korteks renalis yang mengakibatkan perbedaan echotexture yang semakin mencolok pada kortikomedularis. Hal ini diasosiasikan dengan penyakit glumerulonefritis, interstitial nefritis akut, tubular nefritis akut, ethylene glycol toxicity, dimana perubahan echotexture itu mengikuti derajat keparahan penyakit ginjal (Hart, 2013). Sherding (2006) menyatakan bahwa pemeriksaan penunjang pada kucing yang terinfeksi feline infectious peritonitis menunjukkan hasil adanya organomegali baik pada organ hati, ginjal maupun usus.

Hasil pemeriksaan hematologi pada kucing kasus menunjukkan bahwa terjadi leukositosis, granulositosis, limfositopenia. Peningkatan nilai leukosit dan granulosit menunjukkan bahwa adanya infeksi yang menyebabkan peradangan kronis. Sedangkan penurunan kadar limfosit merupakan kompensasi dari peningkatan leukosit dan granulosit.
Sherding (2006) menyatakan bahwa hasil pemeriksaan hematologi kucing yang terinfeksi feline infectious peritonitis menunjukkan terjadinya neutropenia, limfositopenia dan anemia. Hal serupa dinyatakan oleh Tasker (2018) bahwa meskipun pemeriksaan hematologi pada kucing dengan infeksi feline infectious peritonitis tidak begitu spesifik tetapi berdasarkan beberapa kasus telah dievaluasi terjadinya limfositopenia, neutropenia, dan anemia normokromik.

Hasil pemeriksaan kimia darah pada kucing kasus menunjukkan bahwa terjadi penurunan kadar glukosa, alkaline photsphatase, persentase albumin: globulin, serta terjadi peningkatan pada kadar blood urea nitrogen (BUN). Sharif et al. (2010) menyatakan penurunan rasio albumin dan globulin $(\mathrm{A} / \mathrm{G}<0.8)$ dalam serum menunjukkan probabilitas yang feline infectious peritonitis yang tinggi. Peningkatan kadar BUN mengindikasi adanya keterlibatan organ ginjal pada penyebaran infeksi. Hal serupa didukung oleh pernyataan Sharif et al. (2010) bahwa hasil pemeriksaan biokimia darah pada kasus feline infectious peritonitis dapat menunjukkan keterlibatan beberapa organ diantaranya abdomen yang ditandai dengan adanya abnormalitas kadar enzim hati, bilirubin, dan asam empedu serta keterlibatan organ ginjal yang ditandai dengan peningkatan kadar BUN atau kreatinin.

Hasil abdominocentesis menunjukkan adanya akulumasi cairan berwarna kuning terang dengan konsistensi seperti minyak di dalam rongga abdomen. Sharif et al. (2010) menyatakan bahwa efusi yang terlihat pada feline infectious peritonitis diklasifikasikan sebagai modifikasi transudate menjadi eksudat dengan kandungan protein yang tinggi dan adanya konten seluler. Efusi feline infectious peritonitis mengandung biakan sel yang termasuk makrofag, neutrofil, dan limfosit dalam proporsi rendah (Pedersen, 2014). Hasil uji rivalta menunjukkan hasil positif 
yang ditandai dengan tetesan hasil tetes cairan efusi yang secara perlahan melayang turun ke dasar tabung seperti ubur-ubur (jellyfish like). Singh et al. (2019) menyatakan bahwa hewan dengan gangguan hati kronis yang menyebabkan hipertensi portal intrahepatik, ditandai dengan adanya transudat murni bening pada cairan asitesnya. Cairan tersebut tidak berwarna dan mengandung sedikit sel berinti dengan konsentrasi protein yang lebih sedikit.

\section{SIMPULAN DAN SARAN}

\section{Simpulan}

Kucing kasus didiagnosa terinfeksi feline infectious peritonitis bentuk efusi yang ditandai dengan terjadi asites. Peneguhan diagnosa dilakukan melalui pemeriksaan fisik meliputi pemeriksaan tanda vital dan pemeriksaan sistem organ serta pemeriksaan penunjang meliputi pemeriksaan hematologi, rontgen, ultrasonografi, biokimia darah, abdominocentesis, dan tes rivalta. Pengobatan yang diberikan memberikan hasil yang baik terhadap penurunan derajat distensi abdomen.

\section{Saran}

Perlu pemantauan lebih lanjut terkait perkembangan kondisi kucing kasus. Selain itu, perlu dilakukan penelitian lebih lanjut terkait metode diagnosa feline infectious peritonitis bentuk efusi dengan tanda klinis terjadinya asites pada kucing yang terinfeksi.

\section{UCAPAN TERIMA KASIH}

Ucapan terima kasih kepada Direktur dan tenaga medik veteriner Rumah Sakit Hewan Pendidikan Universitas Udayana dalam memberikan fasilitas dan dukungannya.

\section{DAFTAR PUSTAKA}

Andrew SE. 2020. Infectious disease and the eye: feline infectious peritonitis. Veterinary Clinic of North America:
Small Animal Practice 30 (5): 9871000.

Dabas VS, Suthar DN, Chaudhari CF, Modi LC, Vihol PD. 2011. Ascites of spleenic origin in a mongrel female dog - a case report. Vet. World 4(8): 376-377.

Fan YK, Hsu JC, Peh HC, Tsang CL, Cheng SP, Chiu SC, Ju JC. 2002. The effects of endurance training on the hemogram of the horse. AsianAustralasian J. Anim. Sci. 15(9): 13481353.

Felten S, Hartmann K. 2019. Diagnosis of feline infectious peritonitis: a review of the current literature. Viruses. 11(1068): 1-35.

Fischer Y, Sauter-Louis C, Hartmann K. 2012. Diagnostic accuracy of the rivalta test for feline infectious peritonitis. Vet. Clin. Pathol. 41(4): 558-567.

Griffin S. 2019. Feline abdominal utrasonography: what's normal? what's abnormal? J. Feline Med. Surg. 21(11): 1047-1060.

Harkin KR. 2016. Uncovering the cause of fever in dogs. Today's Vet. Pract. 6(4): 34-39.

Hart DV, Winter MD, Conway J, Berry CR. 2013. Ultrasound appearance of the outer medulla in dogs without renal dysfunction. Vet. Radiol. Ultrasound. 54(6): 652-658.

Hartmann K. 2005. Feline infectious peritonitis. Vet. Clin. Small Anim. Pract. 35(1): 39-79.

Horhogea C, Laiu I, Le Poder S, CarpCărare M, Rîmbu C, Carp-Cărare C. 2011. Identification of coronaviral antibodies and coronavirus-specific antibody complexes in ascites fluid of cats diagnosticated with feline infectious peritonitis. Cercetari Agronomice in Moldova (Romania) 44(2): 87-93

Keat K, Subramaniam P, Ghazali S, Amin N. 2016. Review on benefits of owning companion dogs among older adults. 
Mediterranean J. Soc. Sci. 7(4): 397405

Klaassen JK. 1999. Reference Values in Veterinary Medicine. Lab. Med. 30(3): 194-197.

Kumar KS, Srilaka D. 2014. Ascites with right heart failure in a dog: diagnosis and management. J. Adv.Vet. Anim. Res 1(3): 140-144.

Kusumawardhani SW, Haryani CA, Aji YL, Widyaastuti VM. 2019. Catatan Dokter Hewam: Penyakit infeksius pada kucing. Bogor: IPB Press

Lenz K, Buder R, Kapun L, Voglmayr, M. 2015. Treatment and anagement of ascites and hepatorenal syndrome: an update. Ther. Adv. Gastroenterol. 8(2): 83-100.

Neelam, Bhagwan J, Jain VK. 2019. Ascites in a bully female pup - a case report. Int. J. Curr. Microbiol. App. Sci. 8(2): 2949-2951.

Pedersen NC. 2014. An update on feline infectious peritonitis: diagnostics and therapeutic. Vet. J. 201(2): 133-141

Regmi B, Shah MK. 2017. A case study on ascites of hepatic origin and their proper management in a male german shepherd dog. Int. J. Appl. Sci. Biotechnol 5(4): 555-558.

Saravanan M, Mondal DB, Sarma K, Mahendran K, Vijayakumar H, Sasikala V. 2014. Comprehensive study of haemato-biochemical, ascitic fluid analysis and ultrasonography in the diagnosis of ascites due to hepatobiliary disorders in dog. Indian J. Anim. Sci. 84(5): 503-506.

Sharif S, Arshad SS, Hair-Bejo M, Omar AR, Zeenathul NA, Alazawy A. 2010. Diagnostic methods for feline coronavirus: a review. Vet. Med. Int. 2010(809480): 1-7.

Sherding RG. 2006. Feline infectious peritonitis (feline coronavirus). In Saunders Manual of Small Animal Practice. Philadelpia: Elsevier Health Sciences.

Sifa-Shaida AH, Yasmin AR, Nur-Fazila $\mathrm{SH}$, Ain-Fatin R, Ayuni WN, Alif Z, Zuhir H. 2020. A case report of wet form feline infectious peritonitis (FIP) in a domestic short hair cat. Adv. Anim. Vet. Sci. 8(10): 1045-1049.

Singh SK, Shukla SK, Bhatt P, Singh AK. 2019. Clinico therapeutic studies on ascites in canines. Int. J. Curr. Microbiol. App. Sci. 8(9): 1120-1137.

Srinivas AH, Lakshmi TVK, Rao JRK. 2020. Successful management of ascites of hepatic origin in a pup. Int. J. Curr. Microbiol. App. Sci. 9(1): 269273.

Tasker S. 2018. Diagnosis of feline infectious peritonitis, update on evidence supporting available test. $J$. Feline Med. Surg. 20(3): 228-243. 